\title{
Restoring Rapa Nui: The Navel of the Earth
}

Rapa Nui is a small, geographically remote island located in the South Pacific Ocean about 2,300 miles west of Chile and 2,500 miles east of the iconic Polynesian island of Tahiti. But, an isolated location has not kept it from the rest of the world. Rapa Nui is better known as Easter Island (Isla de Pascua) — the island where the native population erected hundreds of giant stone statues (moai), and then basically disappeared. Given their size and quantity, these statues have naturally been a source of mystery and interest for archaeologists and others, including one-the Swiss writer Erik von Däniken — who postulated that the statutes were the work of an extraterrestrial race. But, the story of Rapa Nui and its enormous statutes is not science fiction. Instead, the statutes represent a clue to what happened on Rapa Nui prior to the arrival of the first European explorers, led by Jacob Roggeveen, in 1722.

We know what happened on Rapa Nui thanks to the work and writings of people such as Jo Anne Van Tilburg (Easter Island: Archaeology, Ecology, and Culture; 1994), Grant McCall (Rapanui: Tradition $\mathcal{E}$ Survival on Easter Island, 1994), and Patricia Vargas C. and her colleagues (Estudios del Asentamiento en Isla de Pascua, 1990), among others. It is a complicated history of human interaction with an island environment-a centurieslong dance that produced beauty, identity and honor, but at a terrible price. I want to briefly describe that history and then suggest how restorationists might play an important role in the future of Rapa Nui and its people.

Geologically, Rapa Nui is the end result of three volcanic episodes that occurred within the last million to several million years. Physically, it is 14 miles long by 7 miles wide, triangular in shape with large craters at its three corners, and rolling, weathered volcanic hills and small valleys in between. Geographically, the island lies just outside the tropics, being as far south as Miami is north, which makes it difficult to grow some typical tropical crops. The volcanic soils are highly porous and the supply of freshwater is limited. Rainfall averages about 50 inches per year. The island does, however, experience cycles of severe drought. Windy conditions, which promote rapid evapo-transpiration, are quite common. Finally, unlike many other Pacific islands, Rapa Nui has no atoll because the surrounding ocean is too cold to support the growth of coral.

According to archaeologists, Rapa Nui was settled sometime between A.D. 400-900 - the last of the many islands and island groups in the Pacific inhabited by Polynesian peoples. Pollen studies show that at the time of their arrival, the island was heav- ily forested with several hardwoods species and a species of giant palm (Paschalococus disperta). Fossil records also indicate that Rapa Nui was home to one of the richest assemblages of sea and terrestrial birds in the entire Pacific. These included six native land bird species-a heron, two rails, two parrots, and a barn owl - and 25 species of nesting sea birds.

While the earliest Polynesians on Rapa Nui were small in number, their population expanded to as many as 10,000 people by sixteenth century. Archaeological studies show the record of their resource use, which became more and more intense as the population grew, and as community supported quarrying, carving, and installing of moai to honor their ancestors became increasingly prevalent. This activity was a carefully conceived endeavor, as one might expect when working with stone figures that averaged 12-25 feet in height and 30 tons in weight, and were moved miles from the quarry to their earthen platforms $(a h u)$. All of these tasks were done by human power alone and required the political and economic support of the community - and the support of the island's fragile ecosystems. As a result, the forests were cleared to grow crops such as bananas, taro, sweet potato, sugarcane, and paper mulberry to support the growing population. Stone structures were erected to protect and corral the only livestock - chickens - and large stones were used as windbreaks to protect plants from being dried out by wind. Lithic mulches were used for taro plantings.

Clearing the forest created several problems, however. Not the least of these were severe soil erosion, the loss of organic matter from roosting colonies of birds, and the loss of woody species for making seaworthy vessels. By the sixteenth century, the forests were virtually gone and when an extended drought occurred the people of Rapa Nui were left with few resources. They were also without the means to obtain them from the ocean or the ability to move to another island. Instead, their culture shifted away from erecting moai and embraced what had been a minor ritual practiced by the fishing kinship groups. Known to archaeologists as the birdman cult, this expanded ritual occurred annually and gave the kingship of the island to the kinship group of the first man to swim to an offshore island (Moto Nui) and find an egg of a sooty tern. Switching to such a ritual was an attempt to realign the community to focus on its survival and away from warfare. In worked to some extent, but the population declined nonetheless and their material wealth did as well.

With the arrival of the European explorers, Rapa Nui culture, which was already adrift, was changed forever. Spanish explorers arrived and claimed the island for Spain in 1770 . 
Kidnapping and slavery began in 1805, and climaxed in 1862-63 when European "blackbirders" removed half of the 3,500 native people from Rapa Nui and sold them to landowners and others in Peru. Tuberculosis and smallpox wracked the remaining population until, in 1872, there were only 111 native peoples left! Chile annexed the island in 1888 , but the government forced the native people to live in one village and to work for a Chileanowned sheep ranch. By 1934, sheep, goats, and horses had decimated the remaining native vegetation. It wasn't until 1966 that the islanders become citizens of Chilean citizens and where allowed to move freely about the island. The population is now about 2,500 with other Rapanui living in Chile, Tahiti, and North America.

Jared Diamond, a professor of geography at UCLA and author of the Pulitzer Prize-winning book, Guns, Germs, and Steel: The Fate of Human Societies (1997), devotes an entire chapter to Rapa Nui in his latest bestseller, Collapse: How Societies Choose to Fail or Succeed (2005). In it, Diamond writes: "The overall picture of Easter [Island] is the most extreme example of forest destruction in the Pacific, and among the most extreme in the world: the whole forest gone, and all of its tree species extinct. Immediate consequences for the islanders were losses of raw materials, losses of wild-caught foods, and decreased crop yields" (p. 107). Diamond concludes that Rapa Nui may serve as metaphor to highlight the dangers we may face: "When the Easter Islanders got into difficulties, there was nowhere to which they could flee, nor to which they could turn for help; nor shall we modern Earthlings have recourse elsewhere if our troubles increase. Those are reasons why people see the collapse of Easter Island society as a metaphor, a worst-case scenario, for what may lie ahead of us in our own future" (p. 119).

While I don't want to dismiss Diamond's dire warning, I would like to suggest that Rapa Nui could also serve as focal point for what we can do to restore both an environment and a culture that has been lost. I would like to propose that we create the Rapa Nui Restoration Initiative as a means of restoring the island and bringing international attention to the potential of environmental and cultural restoration.

What, if anything, do we have going for us? Several things come to mind. First, Ecological restorationists have a long-held interest in working with indigenous peoples. Working through SER International's Indigenous Peoples Network, or through other means, could provide the method for establishing the necessary relationships with indigenous Rapa Nui people. Second, we would be working on a relatively small island where we could use a phased restoration process that would by necessity involve soil restoration, lithic mulches, and planting woody plants to begin to ameliorate the environment and provide habitat for birds, whose nutrient-rich droppings would help the soils and possibly provide seeds of other species. Third, the following deciduous species could be obtained from other islands: Alphitonia cf. zizyphoides, which is found on Fiji, Tonga, and Samoa, and Elaeocarpus cf. rarotongensis, which is found on Cook Island and Rarotanga. Both of these species are used for making canoes.
Triumfetta semitriloba, which is native to the Galapagos, and is now found on Hawaii, Guam and other Pacific islands, is used for making rope. Broussonetia papyrifera, which is found throughout Polynesia where it is known as wauke, is used to make tapa cloth. Psydrax odorata, which is found on Hawaii and Micronesia, is used to make harpoons and outriggers. Syzygium malaccense or Malay apple is a fruit that is found in southeast Asia and throughout much of Polynesia. Thespesia populanea or oceanic rosewood is a fine wood for carving and oil can be obtained from its seeds. Sophora toromiro, which is also a carving wood as well as a firewood. Thor Heyerdahl found a toromiro during a 1956 visit to Rapa Nui. Conservation efforts to maintain ex situ populations of toromiro are underway, especially at the Jardín Botanico Nacional in Viña del Mar, Chile. Fourth, we have working examples of similar island projects, including David Wingate's project on Nonesuch Island in the Bahamas; the USF\&WS Hawaiian Offshore Island Working Group's activities on the lesser-known, smaller islands in the Hawaiian chain; and the efforts of the Royal Botanic Garden at Kew to advance the role of endemic species conservation on St. Helena Island in the South Atlantic. Fifth, much of the historical ecology work regarding the reference system has been done by the archaeologists mentioned above.

Now, I'm not kidding myself or anyone else. This would be a huge undertaking. It would first and foremost require establishing a solid working relationship with the present population on Rapa Nui-a population that I suspect has yet to work through much of the psychological and interpersonal damage that was done to it during the past 150 years. Moreover, the environment of Rapa Nui is likewise very fragile and leaves little room for error, especially in times of changing climate. Of course, the logistics of getting to the island are also a challenge. Finally, most, if not all, of the plant material needed will have to brought in from elsewhere because, as recent botanical surveys show, only 48 native plant species exist on the island - a few small trees, some ferns, grasses, sedges, and shrubs.

To undertake such an operation will require the coordination and cooperation of a variety of organizations, arboreta, botanic gardens, and restorationists throughout the world. An interdisciplinary approach that works with local people, Chilean researchers and officials, and international researchers will be paramount. Of course, financial backing will be required. In addition to other monies, perhaps Dr. Diamond, who is no stranger to restoration having written a chapter for Bill Jordan's classic book, Restoration Ecology: A Synthetic Approach to Ecological Research (1987), might contribute some funds from the proceeds of his latest bestseller.

In the end, however, the restoration of Rapa Nui would provide a unique opportunity for scientists, practitioners, administrators, and policymakers to make a statement about the positive relationship human beings can have with their environment. Let's get started!

Te pito o te henua - the navel of the earth-what a place to consider.

Dave Egan 